\title{
Perjuangan Jendral Soedirman Dalam Perang Gerilya Untuk Menumbuhkan Karakter Kepemimpinan Siswa SMA
}

\author{
Shofia Hamdallah Mukti \\ Universitas Sebelas Maret \\ shofiahamdallahmukti@student.uns.ac.id
}

\section{Article History}

received 1/9/2021

revised $1 / 10 / 2021$

accepted 1/11/2021

\begin{abstract}
This study aims to analyze the struggle of General Sudirman in the Gerilya War to foster character education in high school students. The Gerilya War, which became the strategy of the Indonesian struggle led by General Sudirman, had a leadership concept to emulate together. For the freedom fighters of the Republic of Indonesia, Sudirman was not only a commander, but also a symbol of resistance to colonialism. He is also known as a wise open-minded leader and can always find a solution to every problem he faces. Through a literature study approach, this research tries to explain the concept of leadership that exists in the figure of General Sudirman with the character education of students in high school. Based on the results of the analysis that the Gerilya War Struggle led by General Sudirman has heroic values, both from his biography and leadership character from gerilya warfare. This leadership character must exist in the next generation, especially for high school students. It is hoped that the next generation will have an unyielding, courageous, optimistic spirit in facing the challenges of world globalization, so it is necessary to instill a tough character that comes from the leadership of General Sudirman in liberating the State of Indonesia.
\end{abstract}

Keywords : General Soedirman, Gerilya War, Character Education

\begin{abstract}
Kajian ini bertujuan untuk menganalisis perjuangan Jendral Soedirman dalam Perang Gerilya untuk menumbuhkan pendidikan karakter siswa di SMA. Perang Gerilya yang menjadi stategi perjuangan Indonesia yang dipimpin oleh Jendral Soedirman memiliki konsep kepemimpinan untuk diteladani bersama. Bagi para pejuang kemerdekaan Republik Indonesia, Soedirman tidak hanya sekadar seorang panglima, namun juga sebagai simbol perlawanan terhadap kolonialisme. Beliau dikenal juga sebagai pemimpin berpikiran terbuka bijaksana dan selalu dapat menemukan solusi atas setiap masalah yang dihadapi. Melalui pendekatan studi pustaka, penelitian ini berusaha memaparkan konsep kepemimpinan yang ada didalam tokoh Jendral Soedirman dengan pendidikan karakter siswa di SMA. Berdasarkan hasil analisis bahwa Perjuangan Perang Gerilya yang dipimpin oleh Jendral Soedirman memiliki nilai-nilai kepahlawanannya, baik dari biografi maupun karakter kepemimpinannya dari perang gerilya. Karakter kepemimpinan inilah yang harus ada dalam generasi penerus khususnya bagi siswa SMA. Diharapkan, generasi penerus bangsa mempunyai jiwa pantang menyerah, berani, optimis dalam menghadapi tantangan globalisasi dunia maka perlu ditanamkan karakter tangguh yang bersumber dari kepemimpinan Jendral Soedirman dalam memerdekakan Negara Indonesia.

Kata kunci : Jendral Soedirman, Perang Gerilya, Pendidikan Karakter
\end{abstract}

Social, Humanities, and Education Studies (SHEs): Conference Series https://jurnal.uns.ac.id/shes

p-ISSN 2620-9284

e-ISSN 2620-9292 
SHEs: Conference Series 5 (1) (2022) 239- 246

\section{PENDAHULUAN}

Kepemimpinan secara harfian berasal dari kata pimpin. Kata pimpin mengandung pengertian mengarahkan, membina atau mengatur, menuntun dan juga menunjukkan ataupun mempengaruhi. Menurut Wahjosumidjo (2005: 17) kepemimpinan di terjemahkan kedalam istilah sifat- sifat, perilaku pribadi, pengaruh terhadap orang lain, pola- pola, interaksi, hubungan kerja sama antarperan, kedudukan dari satu jabatan administratif, dan persuasif, dan persepsi dari lain-lain tentang legitimasi pengaruh. Kemudian Miftah Thoha (2010: 9) menambahkan bahwa kepemimpinan adalah kegiatan untuk memengaruhi perilaku orang lain, atau seni memengaruhi perilaku manusia baik perorangan maupun kelompok. Kepemimpinan merupakan salah satu faktor yang sangat penting karena sebagian besar keberhasilan dan kegagalan ditentukan oleh pimpinan.

Negara Indonesia memiliki banyak sekali pemimpin terbaik, salah satunya Jenderal Soedirman. Beliau berperan sebagai perjuangan yang menyelamatkan Indonesia dari penjajahan Belanda. Jenderal Soedirman pada usia muda menjadi seorang guru yang berjuangan mencerdaskan Bangsa dan Negara. Sampai pada akhirnya beliau memutuskan untuk meninggalkan seragam gurunya dan ikut menjadi tentara untuk memerdekakan Indonesia di garda depan perang. Saat memimpin pasukanya beliau sangat menginspirasi dan kharismatik sehingga sangat disegani oleh lawan dan kawannya. Bahkan dalam keadaan sakit beliau masih memimpin pasukannya untuk melawan penjajahan Belanda. Beliau dikenal sebagai pemimpin berpikiran terbuka bijaksana dan selalu dapat menemukan solusi atas setiap masalah yang dihadapi (Susilo, 2016: 15). Jendral Soedirman tidak hanya sekadar seorang panglima, namun juga sebagai simbol perlawanan terhadap kolonialisme, bahkan dengan dengan strategi perang gerilyanya menjadi strategi yang berhasil mengusir Belanda dari Indonesia.

Dari kepemimpinan Jendral Soedirman, dapat diambil nilai- nilai kepahlawanannya, baik dari biografi maupun karakter kepemimpinannya dari perang gerilya. Karakter kepemimpinan inilah yang harus ada dalam generasi penerus khususnya bagi siswa SMA. Menurut Muchlas Samani $(2011,43)$ berpendapat bahwa karakter dapat dimaknai sebagai nilai dasar yang membangun pribadi seseorang,

terbentuk baik karena pengaruh hereditas maupun pengaruh lingkungan, yang membedakannya dengan karakternya dengan orang lain dalam kehidupan sehari-hari. Karakter adalah ciri khas yang dimiliki oleh suatu benda atau individu. Ciri khas tersebut asli dan mengakar pada kepribadian benda atau individu tersebut, dan merupakan mesin yang mendorong bagaimana seseorang bertindak, bersikap, berujar, dan merespon sesuatu (Asmani, 2011: 23). Selanjutnya, menurut Maksudin yang dimaksud karakter adalah ciri khas setiap individu berkenaan dengan jati dirinya (daya qalbu), yang merupakan saripati kualitas batiniah/rohaniah, cara berpikir, cara berperilaku (sikap dan perbuatan lahiriah) hidup seseorang dan bekerja sama baik dalam keluarga, masyarakat, bangsa maupun negara (Maksudin, 2013: 3). Dari pendapat para ahli di atas, dapat disimpulkan bahwa karakter adalah sesuatu yang terdapat pada individu yang menjadi ciri khas kepribadian individu yang berbeda dengan orang lain berupa sikap, pikiran, dan tindakan. Ciri khas tiap individu tersebut berguna untuk hidup dan bekerja sama, baik dalam lingkup keluarga, masyarakat, bangsa dan negara. Karakter itulah yang ingin penulis sampaikan untuk meneladani nilai-nilai dari kisah Jendral Soedirman. Hal ini dalam rangka menciptakan kehidupan yang lebih baik di masa mendatang.

\section{METODE}

Kepemimpinan secara harfian berasal dari kata pimpin. Kata pimpin mengandung pengertian mengarahkan, membina atau mengatur, menuntun dan juga menunjukkan ataupun mempengaruhi. Menurut Wahjosumidjo (2005: 17) kepemimpinan 
SHEs: Conference Series 5 (1) (2022) 239- 246

di terjemahkan kedalam istilah sifat- sifat, perilaku pribadi, pengaruh terhadap orang lain, pola- pola, interaksi, hubungan kerja sama antarperan, kedudukan dari satu jabatan administratif, dan persuasif, dan persepsi dari lain-lain tentang legitimasi pengaruh.

Karakter dimaknai sebagai cara berfikir dan berperilaku yang khas tiap individu untuk hidup dan bekerja sama, baik dalam ruang lingkup keluarga, masyarakat, bangsa dan negara. Individu yang berkarakter baik adalah individu yang dapat membuat

keputusan dan siap mempertanggungjawabkan setiap akibat dan keputusannya. Menurut Scerenko dalam Samani (2012: 42) mendefinisikan karakter sebagai atribut atau ciri-ciri yang membentuk dan membedakan ciri pribadi, ciri etis dan kompleksitas mental seseorang, suatu kelompok atau bangsa. Pendidikan karakter merupakan pendidikan nilai, yang mencangkup sembilan nilai dasar yang saling terkait, yaitu (1) responsibility (tanggung jawab), (2) respect (rasa hormat), (3) fairness (keadilan), (4) courage

(keberanian), (5) honesty (kejujuran), (6) citizenship (rasa kebangsaan), (7) caring (peduli) dan perseverance (ketekunan) (Goleman dalam Adisusilo, 2012: 79). Pembahasan ini dikaji menggunakan metode pustaka. Metode tersebut dilakukan dengan memanfaatkan sumber pustaka yang telah tersedia untuk memperoleh data yang diperlukan. Menurut Zed (2004:4-5), metode studi pustaka memiliki empat ciri, antara lain: (1) peneliti berhadapan langsung dengan teks; (2) data pustaka bersifaat siap pakai; (3) data pustaka umumnya merupakan sumber sekunder; dan (4) kondisi data pustaka tidak dibatasi ruang dan waktu. Dalam pembahasan ini, pustaka yang digunakan adalah buku dan artikel jurnal mengenaik kepemimpinan Jendar Soedirman dalam perag gerilya dan nilai karakter dari kepepimpinan Jendral Soedirman. Setelah mengumpulkan pustaka sesuai dengan tema, penulis kemudian membaca dan menuliskan pernyataan pernyataan yang dianggap berkaitan dengan pokok bahasan.

\section{A. Biografi Jendral Soedirman}

\section{HASIL DAN PEMBAHASAN}

Pada tahun 1916 adalah kelahiran Jenderal Soedirman di Desa Karangjati Purbalingga Jawa Tengah dan wafat di tahun 1950. Sejak usia delapan tahun Soedirman diadopsi oleh kerabat Siyem Raden Tjokrosoenarjo. Dari tahun 1923 hingga 1930 Soedirman mengenyam pendidikan dasar di Holland Inlandsch School HIS di Chirakapa dan kemudian di MULO Taman Siswa Satu, kemudian pada tahun berikutnya ia dipindahkan ke Kolese Parama Wiworotomo (Sardiman, 2008: 6). Tiga guru yang mempengaruhi pembentukan karakternya yaitu Laden Sumoyo Laden Mohammed Hollier dan Tirso Subono. Tahun 1936, Soedirman diangkat menjadi guru di HIS

Muhammadiyah Cilacap (Sekolah Dasar) di usia kurang lebih 19-20 tahun (Susilo, 2016: 15).

Selama menjadi guru, Soedirman dikenal sering mengandalkan dialog dan bertutur tentang kehidupan yang dialami oleh para nabi dan kisah wayang untuk mengajarkan soal moral kepada muridnya. Sifatnya yang sabar dan adil dalam memberi penjelasan kepada muridnya, dia termasuk salah satu guru yang populer pada saat itu.

Pada tahun yang sama, Soedirman diangkat sebagai kepala seolah HIS Muhammadiyah Cilacap la dikenal sebagai pemimpin berpikiran terbuka bijaksana dan selalu dapat menemukan solusi atas setiap masalah yang dihadapi (Susilo, 2016: 15). Tidak hanya itu, Soedirman juga memiliki jiwa patriotis yang tinggi, sehingga beliau tidak hanya menjadi guru tetapi juga terjun langsung di medan laga untuk berjuang dalam memerdekakan Indonesia.

Bagi para pejuang kemerdekaan Republik Indonesia, Soedirman tidak hanya sekadar seorang panglima, namun juga sebagai simbol perlawanan terhadap kolonialisme. Tentara Jepang menutup sekolah Chilachap Muhammadiyah di bawah ajaran Soedirman sebelum memutuskan menjadi tentara. Sekolah tersebut dianggap 
SHEs: Conference Series 5 (1) (2022) 239- 246

sebagai lembaga kolonial Belanda (Aji, 2017: 160-161). Peristiwa inilah yang membuat Soedirman mulai meyakinkan dirinya untuk membela rakyat demi memperjuangkan Kemerdekaan Indonesia dengan cara bergabung dengan pasukan militer. Di dunia militer, Soedirman mengawali kariernya dengan bergabung bersama PETA (Pembela Tanah Air). Selesai mengikuti latihan PETA di Bogor, Jawa Barat. Soedirman diangkat menjadi Daidancho atau Komandan Daidan yang setara dengam Komandan Batalyon, di Kroya, Banyumas. Usai merebut gelar ia ingin mencapai tujuannya yaitu memerdekakan Indonesia pada akhirnya mau tidak mau ia harus melawan penjajah dan angkat senjata Demi mewujudkan mimpinya Soedirman mulai mendidik anak muda dan membawa kecintaannya pada tanah air kepada anak muda Dia ingin membentuk pasukan rakyat revolusioner untuk memuliakan tanah air tercinta.

Kiprah Jenderal Soedirman dalam bidang militer sangat berpengaruh besar di Indonesia sehingga beliau dijuluki dan diberi gelar Bapak Tentara Indonesia. Hal ini dibuktikan dengan perang Gerilya yang dicetuskan dan dilancarkan oleh Soedirman yang berhasil membuat Indonesia merdeka. Selain itu, beliau seorang patriotisme sejati. Dialah jenderal pertama dan termuda dalam sejarah militer Indonesia. Sosoknya yang pendiam memiliki sifat-sifat lembut seorang ksatria, jujur, adil, sabar, sopan santun, dan taat agama. Dimana semua tak terlepas dari sifatnya yang pemberani, konsekuen, keras hati, dan teguh dalam pendirian.

Pada tahun 1945 Soedirman memimpin Tentara Keamanan Rakyat yang merupakan pendahulu TNI. Soedirman disetujui oleh Komandan Tentara Keamanan Rakyat Pada 18 Desember Tahun 1945 (Adi, 2011: 50). Soedirman menerima berbagai penghargaan dari pemerintah pusat setelah kematiannya antara lain Bintang Shakti, Gerilya, Mahaputra Adipurna, Mahaputra Pratama, RI Adipurna dan Bintang RI Adipradana. Pada tanggal 10 Desember 1964 berdasarkan Keppres No 314 pada tahun 1964 ia dinyatakan sebagai pahlawan nasional dan di tahun 1997 dia dipromosikan menjadi seorang Jenderal. Pada tahun 1950 Soedirman meninggal di Magelang merupakan sosok yang tak pernah henti memperjuangkan kemerdekaan Indonesia.

\section{B. Keadaan Militer Pada Masa Agresi Militer II}

Pasca Proklamasi Kemerdekaan Indonesia, Jawa Tengah menjadi pusat pemerintahan Indonesia. Salah satu kota tang strategis di Jawa Tengah ialah Yogyakarta. Dengan demikian, berbagai kegiatan politik, militer, pemerintahan, serta ekonomi baik yang dilaksanakan oleh pemerintahan maupun non pemerintahan dilaksanakan di kota Yogyakarta (Seskoad, 1991: 109). Selain itu, kota Yogyakarta juga sebagai kekuatan militer Indoneisa yang sangat strategis. Pada saat itu Yogyakarta menjadi sasaran utama dari operasi militer Belanda, karena di kota Yogyakarta menjadi Markas Tertinngi Tentara Keamanan Rakyat (Seskoad, 1991: 107). Dari kota Yogyakarta inilah sega keputusan dan peraturan ketentaraan serta keamanan diatur maupun dikeluarkan. Hal ini dilakukan rangka untuk menyususn kekuatan bersenjata yang dapat menjamin ancaman dari Belanda.

Kota Yogyakarta merupakan salah satu daerah konsentrasi yang dipersiapkan oleh pasukan Tentara Nasional Indonesia (Heijboar, 1998: 168). Yang di mana prajuritnya telah siap mengangkat senjatanya untuk mengawali perjalanan yang panjang demi menghindari pasukan Belanda dengan cara menerobos bukit, sungai, serta hutan hutan. Dari sini dapat dilihat bahwa Jendral Soedirman menunjukkan kecerdasannya sebagai seorang pemimpin. Sebagai seorang pemimpin Soedirman memberikan keyakinan kepada para anggota TNI bahwa tindakan tersebut merupakan tindakan yang pernah diajarkan oleh Nabi Muhammad Shalallahu'alaihi Wa Sallam dan kaum Muhajirin sewaktu berpindah dari kota Makkah ke kota Madinah.

Berpindahnya satu tempat ke tempat yang lainnya, jaringan teritorial yang telah dipersiapkan tetap berjalan sehingga para militer dan pimpinan sipil selalu berhubungan 
SHEs: Conference Series 5 (1) (2022) 239- 246

dengan Panglima Jendral Soedirman. Hierarki kemiliteran tetap berfungsi dan dipegang teguh selama perang gerilya (Susilo, 2018: 73). Dengan adanya strategi berpindah tempat ke tempat lainnya, menunjukkan bahwa Jendral Soedirman selalu siap dalam membuat persiapan-persiapan gerilya untuk menghadapi para penjajahan Belanda.

\section{Perjuangan Jendral Soedirman Dalam Perang Gerilya}

Mulai November 1948, hubungan Indonesia dan Belanda semakin memburuk, karena pada tahun 1948 Belanda melakukan konsentrasi pasukan besar-besaran di garis demarkasi untuk mempersiapkan serangan kembali terhadap Indonesia (Sadirman, 2008: 177. Mendengar berita tersebut, walaupun dalam kondisi sakit, Soedirman tidak tinggal diam untuk membaca kondisi pada saat itu dan juga mampu dalam memberikan strategi perang yang baik serta bisa memberikan motivasi kepada pasukanny untuk berjuang sampai titik darah penghabisan. Selain itu Soedirman tetap melakukan koordinasi dengan para komandan untuk bersiap siaga.

Pada saat Belanda mulai melakukan persiapan penyerangan kembali terhadap Indonesia, Jendral Soedirman segera memerintahkan wakil Panglima Besar yang juga sebagai Panglima Tetara Teritorium Jawa yaitu Kolonel A.H Nasution untuk segera menyusun konsep Perang Rakyat Semesta dengan TNI. Nasution yang merupakan mantan Panglima Divisi Siliwangi, sejak tahun 1948 ditugaskan sebagai wakil Panglima Besar dan ikut berperan di Markas Tertinggi TNI dan juga menjadi salah satu orang kepercayaan Jendral Soedirman. Sebelum membetuk strategi perang gerilya, Jendral Soedirman sudah memikirkan bagaimana jalan keluar untuk menghadapi penjajah Belanda.

Pada tanggal 19 Desember 1948 pasukan Belanda melancarkan serangan terhadap Lapangan Terbang Maguwo (kini Lanuma Adisucipto), kurang lebih enam kilo meter di sebelah timur ibu kota RI Yogyakarta. Dengan serangan itu mulailah Agresi Militer II. Panglima Besar Soedirman segera mengeluarkan Pemerintahan Kilat untuk semua Angkatan Perang agar menjalankan rencana untuk menghadapi Belanda.

Kemudian Jendral Soedriman, membuat konsep yang ditulis tangan langsung oleh Jendral Soedirman sendiri kemudian dibacakan di Radio Republik Indonesia (RRI) Yogyakarta (Tjondronegoro, 1982: 70). Konsep yang disiarkan adalan "Pemerintahan Kilat Soedirman. Pasca dibacakan Perintah Kilat, akhirnya Jendral Soedirman langsung bergerak untuk membentuk strategi perang gerilya. Strategi perang gerilya antara lain; (1) Melepaskan pertahanan di kora besar dan jaringan jalan raya dan membangun kantong-kantong gerilya, (2) Melakukan perang gerilya dan (3) Wingate (kembali ke daerah asal) bagi satuan hijrah ke Yogyakarta setelah Perjanjian Renville seperti Divisi Siliwangi (Wijaya: 2012: 42).

Gerakan pasukan Belanda menuju Yogyakarta baru dimulai sekitar pukul 12.00. oleh Karena itu, kabinet masih sempat bersidang, dalam siding tersebut diambil keputusan bahwa Presiden dan Wakil Presiden tidak akan meninggalkan ibu kota. Ada dua alasan yang dikemukakan. Pertama, tidak ada pasukan yang akan mengawal mereka keluar kota. Kedua, bila tetap tinggal dalam kota, hubungan dengan KTN masih dapat dilakukan dan dengan perantara KTN perundingan dengan Belanda dapat dibuka kembali. Keputusan lain adalah memberikan mandate kepada kepada Menteri Kemakmuran Sjafruddin Prawiranegara yang ketika itu berada di Bukittinggi untuk membentuk pemerintahan darurat di Sumatra. Mandate juga diberikan kepada dr. Sudarsono, A.A. Maramis dan L.N Palar untuk membentuk exile government di luar negeri bila usaha Sjafruddin gagal.

Pada tanggal 19 Desember itu juga Yogyakarta jatuh ke tangan Belanda. Presiden, Wakil Presiden dan sejumlah petinggi negara mereka tawan dan tiga hari kemudian diasingkan ke luar Jawa. Panglima Soedirman berangkat keluar kota memimpin jalannya gerilya. Pada tanggal 22 Desember 1948 PTTD Kolonel Nasution mengumumkan berdirinya pemerintahan militer di Jawa. Sesuai dengan rencana, 
Angkatan perang Perang mengundurkan dirinya ke luar kota untuk melakukan perang gerilya. Pasukan yang tadinya dihijrahkan akibat persetujuan Renville, melakukan wingate ke daerah asal mereka. Pasukan Siliwangi melakukan long march dari Jawa Tengah ke Jawa Barat. Di luar kota, TNI membentuk daerah-daerah pertahanan (wehrkreise). Setelah berhasil melakukan konsolidasi, TNI mulai memberikan pukulan pukulan terhadap Belanda. Pertama kali yang menjadi sasaran adalah garis-garis komunikasi pasukan Belanda. Kawat-kawat telepon diputuskan, jalan-jalan kerta api dirusak, dan konvoi-konvoi Belanda dihadang dan diserang. Oleh karena itu, Belanda terpaksa memperbanyak pos-pos di sepanjang jalan yang menghubungkan kota-kota yang sudah mereka duduki (Poesponegoro \& Notosusanto, 2011: 465). Dengan demikian, kekuatannya terpaku pada ribuan pos kecil yang tersebar di daerah RI yang kini menjadi medan gerilya yang luas.

Situasi peraang pun mulai berbalik. TNI yang awalnya defensive mulai beralih ke ofensif. Serangan tehadap Belanda tidak lagi hanya serupa pencgatan konvoi-konvoi atau terhadap pos-pos Belanda yang terpencil, tetapi juga terdapat kota-kota yang diduduki Belanda. Dibentuknya strategi gerilya tersebut, Soedirman dan pasukannya membuat Belanda kewalahan dalam menghadapi pasukan Jendral Soedirman dan akhirnya Belanda menarik mundur pasukannya di dalam peperangan ini. Strategi perang gerilya yang dimiliki oleh Jendral Soedirman menunjukkan bahwa Jendral Soedirman merupakan seorang pemimpin kharismatik yang memiliki jiwa baik dan semangat juang yang tinggi di dalam memimpin pasukannya dengan memanfaatkan alam sekitar yang ada di Jawa Tengah sebagai benteng pertahanan untuk melawan dan mengusir penjajahan Belanda dari Negara kesatuan Republik Indonesia.

\section{Nilai Karakter Jendral Soedirman}

Karakter dimaknai sebagai cara berfikir dan berperilaku yang khas tiap individu untuk hidup dan bekerja sama, baik dalam ruang lingkup keluarga, masyarakat, bangsa dan negara. Individu yang berkarakter baik adalah individu yang dapat membuat keputusan dan siap mempertanggungjawabkan setiap akibat dan keputusannya. Menurut Scerenko dalam Samani (2012: 42) mendefinisikan karakter sebagai atribut atau ciri-ciri yang membentuk dan membedakan ciri pribadi, ciri etis dan kompleksitas mental seseorang, suatu kelompok atau bangsa.

Pendidikan karakter merupakan pendidikan nilai, yang mencangkup sembilan nilai dasar yang saling terkait, yaitu (1) responsibility (tanggung jawab), (2) respect (rasa hormat), (3) fairness (keadilan), (4) courage (keberanian), (5) honesty (kejujuran), (6) citizenship (rasa kebangsaan), (7) caring (peduli) dan perseverance (ketekunan) (Goleman dalam Adisusilo, 2012: 79). Menurut Scerenko dalam Samani (2012: 45) pendidikan karakter dapat dimaknai sebagai upaya sungguh-sungguh dengan cara mana ciri kepribadian positif dikembangkan, didorong, dan diberdayakan melalui keteladanan, kajian (sejarah, dan biografi para bijak dan pemikir besar) serta praktei emulasi (usaha yang maksimal untuk mewujudkan hikmah dari apa-apa yang diamati dan dipelajari).

Generasi penerus bangsa khususnya siswa SMA harus mempunyai jiwa pantang menyerah, berani, optimis dalam menghadapi tantangan globalisasi dunia maka perlu ditanamkan karakter tangguh. Ketangguhan ditandai oleh tiga hal yaitu komitmen, control, dan tantangan. Karakter tangguh yang dimiliki seseorang dapat membantu mengendalikan tekanan psikologis yang sedang ia alami, mampu memperoleh proses pembelajaran dengan baik, memililiki interaksi yang baik dengan orang lain serta memiliki penilaian positif terhadap dirinya.

Siswa yang mempunyai karakter tangguh akan menikmati tantangan selama proses belajarnya dan terbukti bahwa mereka memiliki perilaku belajar positif dan hampir tidak pernah mengalami putus asa dan dapat menikmati saat mempelajari hal-hal baru. Ketangguhan yang tinggi mampu membuat seseorang menghadapi tuntutan 


\section{SHEs: Conference Series 5 (1) (2022) 239- 246}

tuntutan selama proses pembelajaran dengan usaha terbesar yang mampu ia lakukan dan

akan berusaha mencari cara terbaik untuk dapat keluar dari permasalahan yang sedang dihadapi. Karakter tangguh tersebut merupakan salah satu contoh nilai karakter yang patut diteladani dari Jenderal Soedirman.

Jenderal Soedirman merupakan salah satu pahlawan nasional yang berjuang untuk kemerdekaan republik Indonesia. Semangat kepahlawanan yang diwijudkan merupakan amal perjuangan yang dipersembahkan kepada bangsa dan tanah air dengan jiwa dan semangat rela berkorban untuk bangsanya. Adanya semangat juang yang tinggi, keberanian, rela berkorban, pantang menyerah dan cinta tanah air adalah nilai kepahlawanan yang masih reevan dan pantas dijadikan panutan bagi generasi muda. Oleh karena itu pengenalan nilai-nilai kepahlawanan perlu dilakukan dan disosialisasikan pada generasi muda khususnya siswa SMA.

\section{SIMPULAN}

Bagi para pejuang kemerdekaan Republik Indonesia, Soedirman tidak hanya sekadar seorang panglima, namun juga sebagai simbol perlawanan terhadap kolonialisme. Hal itu ditunjukkan oleh kepintaran Jendral Soedirman dalam membentuk strategi perang gerilya. Strategi perang gerilya antara lain; (1) Melepaskan pertahanan di kora besar dan jaringan jalan raya dan membangun kantong-kantong gerilya, (2) Melakukan perang gerilya dan (3) Wingate (kembali ke daerah asal) bagi satuan hijrah ke Yogyakarta setelah Perjanjian Renville seperti Divisi Siliwangi.

Jenderal Soedirman merupakan salah satu pahlawan nasional yang berjuang untuk kemerdekaan republik Indonesia. Semangat kepahlawanan yang diwijudkan merupakan amal perjuangan yang dipersembahkan kepada bangsa dan tanah air dengan jiwa dan semangat rela berkorban untuk bangsanya. Adanya semangat juang yang tinggi, keberanian, rela berkorban, pantang menyerah dan cinta tanah air adalah nilai kepahlawanan yang masih reevan dan pantas dijadikan panutan bagi generasi muda. Oleh karena itu pengenalan nilai-nilai kepahlawanan perlu dilakukan dan disosialisasikan pada generasi muda.

\section{DAFTAR PUSTAKA}

Adi A. Kresna. (2011). Soedirman: Bapak Tentara Indonesia. Yogyakarta: Mata Padi Pressindo.

Adisusilo, Sutardjo. (2012). Pembelajaran Nilai Karakter. Jakarta: PT. Raja Grafindo Persada.

Aji, Krishna Bayu. (2017). Soedirman: Riwayat Hidup, Perjuangan, dan Kisah Cinta Sang Jenderal. Yogyakarta: Araska, 201.

Heijboer, P. (1998). Agresi Militer Belanda: memperebutkan Pending Zamrud Sepanjang Khatulistiwa 1945-1959. Jakarta: PT Grasindo.

Poesponegoro, M.D. dan Notosusanto, N. (2011). Sejarah Indonesia VI. Jakarta: Balai Pustaka.

Samani, Muchlas. (2011). Konsep dan Model Pendidikan Karakter. Bandung: PT. Remaja Rosdakarya.

Sardiman. (2008). Guru Bangsa: Sebuah Biografi Panglima Besar Jenderal Soedirman. Yogyakarta: Ombak

Seskoad. (1991). Serangan Umum 1 Maret 1949 di Yogyakarta; Latar Belakang dan

Pengaruhnya. Jakarta: PT. Citra Lamtoro Gung Persada.

Susilo, A. (2018). Sejarah Perjuangan Jenderal Soedirman dalam Mempertahankan Indonesia (1945-1950). Dalam Jurnal Historia, Volume 6, Nomor 1, Tahun 2018

Susilo, Taufik Adi, (2016). Soedirman: Biografi Singkat 1916-1950. Yogyakarta: Garasi House of Book. 
SHEs: Conference Series 5 (1) (2022) 239- 246

Tjondronegoro, P. (1982). Merdeka Tanahku, Merdeka Negeriku 2. Jakarta: C.V. Nugraha

Wijaya, A., dkk. (2012). Soedirman: Seorang Panglima, Seorang Martir. Jakarta: Kepustakaan Populer Gramedia. 